\title{
Evaluation of Water Losses: Study Case in Intan Banjar Water Supply Company
}

\author{
Maria Setianingsih $^{1}$ and Nieke Karnaningroem ${ }^{1}$
}

\begin{abstract}
Water losses from water distribution networks have become a crucial problem. The BNA (Basic Need Approach) zone has high water losses above the standard for maximum tolerance ministry of public work as $20 \%$. The water losses during September - December 2018 has experienced a fluctuation. the highest losses occurred in October at $36.05 \%$, but in November the level of water losses decreased to $34.17 \%$. The water balance can be used to know to understand the quantity, source, and charge of water losses. The water balance calculation in this study uses the WB-Easy Calc program version 4.05. Based on the result, the percentage of water losses $34,81 \%$ with the composition of real losses as $30,61 \%$ and apparent losses of $4.21 \%$. On the other hand, the financial impact by the water losses was deficit as Rp. 4.593.648.335. Furthermore, gets to the action for each one of the above main components of the water balance in order to reduce water losses.
\end{abstract}

\section{Keywords-Distribution, Water Balance, Water Losses.}

\section{INTRODUCTION}

Water is one of the important factors in determining human needs. Intan Banjar is a water supply company in Banjar Regency and Banjarbaru City with BNA (Basic Need Approach) is one of theirs service zones. Intan Banjar improves its service performance by reducing water losses. Water losses is the management of the quantity of water different between supply and consumption through the distribution system. The level of water losses in the BNA (Basic Need Approach) is above the standard for maximum tolerance ministry of public work as $20 \%$ [1]. The high level of water losses greatly influences ability to supply clean water to consumers. Water balance is very important in the program to reducing water losses. The water balance can be used for assessing water losses conditions by knowing the details of the components water losses. Water balance is a water calculation method proposed by International Water Association (IWA) at a conference in Berlin in 2001. Being aware of the problem of different water balance formats, methods and leakage performance indicators, the IWA has developed a standard international water balance structure and terminology[2]. This standard format has meanwhile been adopted (with or without modifications) by national associations in a number of countries[3]. Water balance calculation in this study using

\footnotetext{
${ }^{1}$ Maria Setianingsih and Nieke Karnaningroem are with Department of Environmental Engineering, Institut Teknologi Sepuluh Nopember, Indonesia. $\quad$ Email: maria.enviro@gmail.com; n.karnaningroem@gmail.com.
}

the program WB-EasyCalc version 5.16. The aim of this research is to convince Intan Banjar of water supply company with still high of water losses that the introduction water balance will be an important first step towards to reduce water losses in Intan Banjar water supply company. The research also provides recommendations on the best management practices to be considered in order to minimize the water losses and maintain it below the allowable national standard.

\section{LITERATURE REVIEW}

\section{A. Water Balance}

The term Water Balance has long been used to describe the equation of the water coming in and out of a system, expressing the network's losses in a financial form by essentially comparing the value of the originally provided amount of water and therefore the value that should be invoiced to the one actually invoiced after consumption.

\section{B. Apparent and Real Losses}

The difference observed in every Water Balance equation derives from losses throughout the network and its management. These losses can be easily discriminated in apparent losses and real losses. The apparent losses express the amount of water that is not invoiced due to non-authorized consumption and inaccuracies of the metering system which when combined lead to the part of the system's water that is actually consumed, just not paid for. The real losses express the physical substance of water lost due to overflows and leakages throughout the entire network. This is the part of the system's water that never reaches the consumer and therefore is not paid for either. In most developed countries, there are no or very limited apparent losses[4].

\section{METHOD}

The location of this research is urban water distribution network in Intan Banjar water supplay company in BNA (Basic Need Approach). In this research, calculation of water losses from the difference between the amount of water distributed and the amount of water in the customer's account and calculation of water balance was used software WB EasyCalc version 5.16 to calculate the percentage of all the components of the water losses. The data needed to calculate the water balance in the WB-EasyCalc program is the system input volume data, metered consumption data, unmetered consumption data, unbilled meter consumption 
data, unbilled unmetered consumption data, unofficial consumption data, inaccurate data meters and data handling, data on the length of distribution and transmission pipes, official pipeline data, average pressure data, intermittent supply data, and financial data. The data used as input software comes from the report of Monthly production, distribution and Non Revenue Water for 122 days (from September 2018 to December 2018), and by quantitative research method through survey, interview and other observations. After that, the factors determined water losses can be known can action to reduce water losses.

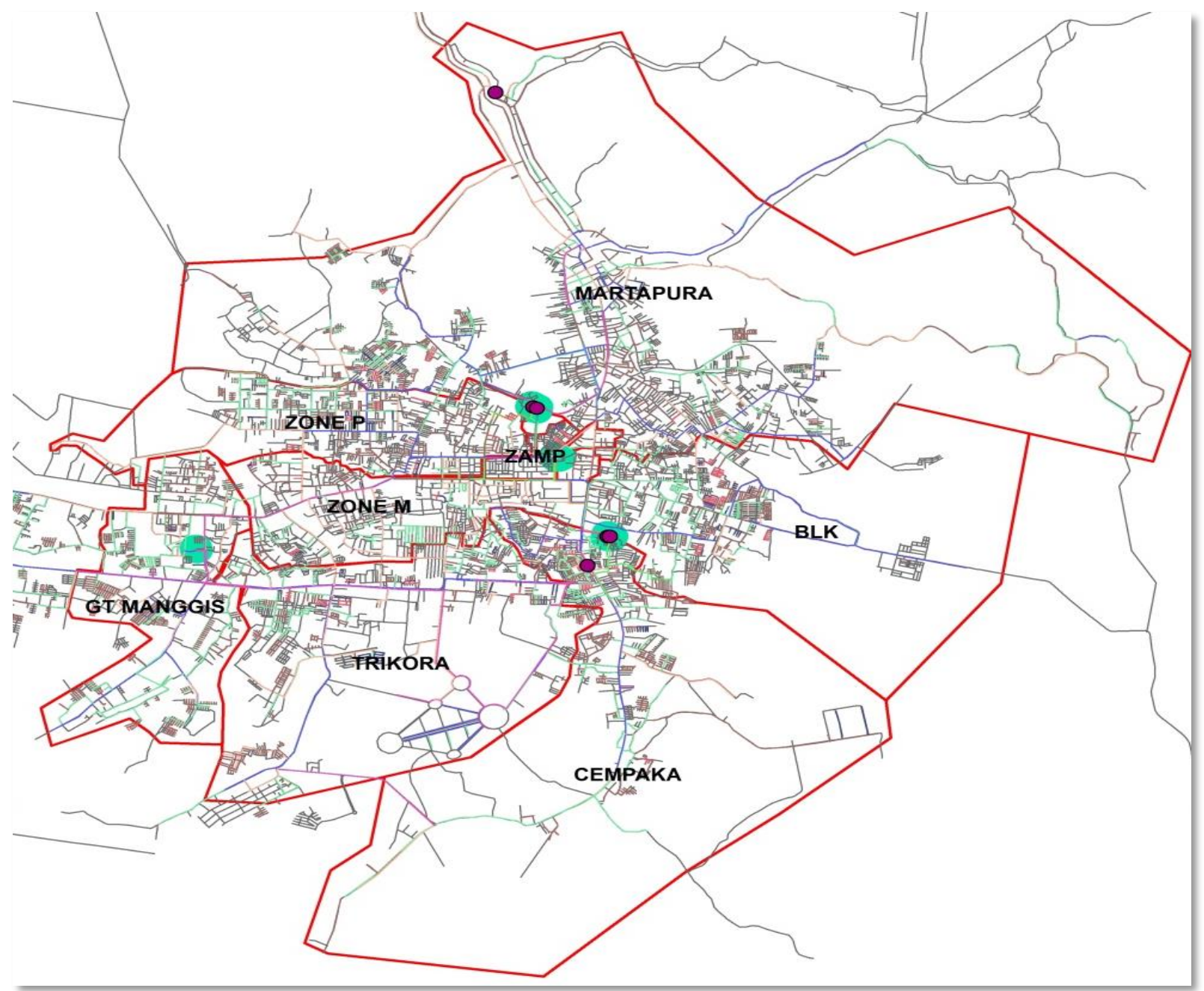

Figure 1. Water Supply Distribution Zone in BNA (Basic Need Approach) Intan Banjar Company

TABLE 1.

BNA CUSTOMER CHARACTERISTICS BASED ON CUSTOMER CLASS PART 1

\begin{tabular}{lcccccccc}
\hline \hline \multirow{2}{*}{ Zona } & \multicolumn{7}{c}{ Customer Class } \\
\cline { 2 - 9 } & General Social & Special Social & Tanker & A1 & A2 & A3 & A4 & A5 \\
\hline Zona M & 59 & 69 & & 6 & 430 & 3833 & 647 & 21 \\
Zona P & 40 & 29 & 1 & 4 & 215 & 2764 & 1594 & 24 \\
Zamp & 5 & 7 & & 1 & 25 & 521 & 422 & 29 \\
MTP & 41 & 89 & & 12 & 1156 & 4326 & 570 & 16 \\
Trikora & 34 & 18 & & & 94 & 5127 & 386 & 23 \\
Cempaka & 41 & 31 & & 31 & 718 & 4043 & 223 & 11 \\
Sei Ulin/BLK & 30 & 23 & & 17 & 274 & 4196 & 266 & 17 \\
TOTAL & 250 & 266 & 1 & 71 & 2.912 & 24.810 & 4.108 & 141 \\
\hline \hline
\end{tabular}


The $1^{\text {st }}$ International Conference on Business and Management of Technology (IConBMT)

August 3rd 2019, Institut Teknologi Sepuluh Nopember, Surabaya, Indonesia

TABLE 2.

BNA CUSTOMER CHARACTERISTICS BASED ON CUSTOMER ClASS PART 2

\begin{tabular}{|c|c|c|c|c|c|c|c|c|}
\hline \multirow{2}{*}{ Zona } & \multicolumn{8}{|c|}{ Customer Class } \\
\hline & $\mathrm{B} / \mathrm{IP}$ & Small Commerce & Intermediate Commerce & Big Commerce & Small industry & Large Industry & Special & $\mathrm{HU}$ \\
\hline Zona $\mathrm{M}$ & 74 & 109 & 664 & 60 & 1 & 1 & & 1 \\
\hline Zona P & 52 & 63 & 598 & 14 & & & & \\
\hline Zamp & 32 & 16 & 187 & 5 & & & & \\
\hline MTP & 98 & 88 & 549 & 35 & 3 & & & 34 \\
\hline Trikora & 48 & 28 & 355 & 9 & & & & 2 \\
\hline Cempaka & 16 & 29 & 143 & 9 & & & & 6 \\
\hline Sei Ulin/BLK & 40 & 50 & 165 & 5 & & & & \\
\hline TOTAL & 360 & 383 & 2.661 & 137 & 4 & 1 & 0 & 43 \\
\hline
\end{tabular}

\section{RESUltS AND DisCUSSION}

BNA (Basic Need Approach) has served 36,148 active customers and has 16 customer classes which most customers are dominated by A3 type with a total of 24,810 SR shown in Table 1 and Table 2.

Base on transmission and distribution section monthly report in the BNA zone has high water losses above the standard for maximum tolerance ministry of public work as $20 \%$. The percentage of water losses is the difference between the amount of water distributed and the amount of water in the customer's account. The percentage of water losses in BNA every month from September 2018 to December 2018 shown in the Table 3, Table 4 and Figure 3.

Based on Table 3, Table 4 and Figure 2, that's shown the water losses on BNA for each month during September December 2018 has experienced a fluctuation. It can be seen that the highest losses occurred in October at $36.05 \%$, but in November the level of water losses decreased to $34.17 \%$. This high level of water losses, the Intan Banjar Company must carry out a reduction program. The first thing that needs to be done in a water loss reduction program is to calculate the water balance. The results of the water balance calculation in the BNA zone for 122 days from September 2018 to December 2018 using the WBEasyCalc program version 5.16 are shown in Figure 3.

Water balance in BNA zone in Intan Banjar water supply company can be described as:

- Annual system input volume September 2018 to December 2018 for BNA zone Intan Banjar water supply company from Pinus and Banjarbakula water treatment have distributed water as $3.239 .062 \mathrm{~m}^{3}$.

- Authorised consumption is the monthly volume of metered and unmetered water taken by registered customers, laboratories,etc. For example water used in fire hydrants and others. The Authorised consumption of the September 2018 to December 2018 as 2,111,439 $\mathrm{m}^{3}$.

- Water losses as Annual system input volume reduced by Authorised consumption. Water losses consists of apparent losses and real losses. So the calculation for Water losses in the September 2018 to December 2018 for BNA zone is 3,239,062 - 2,111,439=1,127,623 $\mathrm{m}^{3}$. When changed in percentage is $34.81 \%$.

- Billed Authorised Consumption is the volume of metered or unmetered monthly water used by registered customers. In BNA zone during September 2018 to December 2018 currently has no billed unmeterd consumption and only a billed metered consumption meter as 2,097,044 $\mathrm{m}^{3}$.

- Unbilled authorized consumption is authorised consumption reduced by billed authorised consumption. So calculation of unbilled authorized consumption in the September 2018 to December 2018 for BNA zone is $2,111,439-2,097,044=14,395 \mathrm{~m}^{3}$.

- Revenue water is billed metered consumption plus billed unmetered consumption. So that the calculation for revenue water for September 2018 to December 2018 in the BNA zone is 2,097,044 + $0=2,097,044 \mathrm{~m}^{3}$.

- Unbilled metered Consumption is water for customers with installed meters but the company dont't charge for collect water or free usage fees. At present, in the Intan Banjar company haven't unbilled metered consumption, so during September 2018 to December 2018 of unbilled meter consumption is $0 \mathrm{~m}^{3}$.

- Unbilled unmetered consumption is all official consumption which is not billed or not metered. This component is used for water supplay company operations such as washing pipes, pipe tests, roads cleaning, etc. Unbilled unmetered consumption as Unbilled authorized consumption which is reduced by unbilled metered consumption. So the calculation during September 2018 to December 2018 is 14,495 - 0 $=14,395 \mathrm{~m}^{3}$.

- Unauthorized consumption is unknown use of water. Unauthorized consumption is an illegal connection, bypass on the meter, Unauthorized use hydrant, etc. Unauthorized consumption in September 2018 to December 2018 BNA zone is $4,685 \mathrm{~m}^{3}$.

- Customer metering inaccuracies and data handling errors ia an apparent loses due to customer meter 
inaccuracies and errors in meter reading. Inaccuracy of meters and data handling in September 2018 to December 2018 its value is $131,553 \mathrm{~m}^{3}$.

- Commercial losses or Apparent losses are Unauthorized consumption plus meter inaccuracies and data handling. So that the calculation of Apparent losses in September 2018 to December 2018 for BNA zone is $4.685+$ $131.553=136,238 \mathrm{~m}^{3}$. When changed in the percentage is $4.21 \%$.
- Physical losses sometimes called 'real losses' are the annual volumes lost through all types of leaks, bursts, and overflows in pipes, service reservoirs and service connection, up to the point of the customer meter. Real Losses as water losses reduced by apparent losses, so that the Calculation of real losses is 1.127.623 $136.238=991,385 \mathrm{~m}^{3}$. When changed in percentage, it is $30.61 \%$.

TABEL 3.

Calculation of Percentage of Water Losses in SePtember - October Per Zone

\begin{tabular}{|c|c|c|c|c|c|c|c|c|c|c|}
\hline \multicolumn{3}{|c|}{ Description } & \multicolumn{4}{|c|}{ Sep-18 } & \multicolumn{4}{|c|}{ Okt-18 } \\
\hline \multirow{2}{*}{ Input } & \multirow{2}{*}{\multicolumn{2}{|c|}{ Zone }} & \multirow{2}{*}{$\begin{array}{c}\text { Water } \\
\text { Distributed }\end{array}$} & \multirow{2}{*}{$\frac{\text { Sold water }}{\text { M3 }}$} & \multicolumn{2}{|c|}{$\%$ Water Losses } & \multirow{2}{*}{$\begin{array}{c}\text { Water } \\
\text { Distributed }\end{array}$} & \multirow{2}{*}{$\begin{array}{c}\text { Sold water } \\
\text { M3 }\end{array}$} & \multicolumn{2}{|c|}{$\%$ Water Losses } \\
\hline & & & & & M3 & $\%$ & & & M3 & $\%$ \\
\hline \multirow{4}{*}{ IPA PINUS } & Zona M & & 155.603 & 117.916 & 37.687 & $24,22 \%$ & 146.301 & 114.467 & 31.834 & $21,76 \%$ \\
\hline & Zona P & & 113.117 & 78.413 & 34.704 & $30,68 \%$ & 107.191 & 77.088 & 30.103 & $28,08 \%$ \\
\hline & Zamp & & 30.322 & 22.819 & 7.503 & $24,74 \%$ & 29.099 & 21.573 & 7.526 & $25,86 \%$ \\
\hline & MTP & & 171.659 & 102.289 & 69.370 & $40,41 \%$ & 169.388 & 94.511 & 74.877 & $44,20 \%$ \\
\hline \multirow{3}{*}{$\begin{array}{c}\text { IPA } \\
\text { Banjarbakula + } \\
\text { IPA Pinus }\end{array}$} & \multirow{3}{*}{$\begin{array}{c}\text { Boster } \\
\text { Muslimin }\end{array}$} & Trikora & 102.608 & $63.751,00$ & 38.857 & $37,87 \%$ & 114252 & 66.324 & 47.928 & $41,95 \%$ \\
\hline & & Cempaka & 117.320 & $73.070,00$ & 44.250 & $37,72 \%$ & 128839,5 & 70.794 & 58.046 & $45,05 \%$ \\
\hline & & Sei Ulin/BLK & 108.779 & $72.684,00$ & 36.095 & $33,18 \%$ & 109590,98 & 69.817 & 39.774 & $36,29 \%$ \\
\hline & TOTAL & & 799.408 & 530.942 & 268.466 & $33,58 \%$ & 804.661 & 514.574 & 290.087 & $36,05 \%$ \\
\hline
\end{tabular}

TABEL 4.

CAlculation of Percentage of Water Losses in November - DeCember Per Zone

\begin{tabular}{|c|c|c|c|c|c|c|c|c|c|c|}
\hline \multicolumn{3}{|c|}{ Description } & \multicolumn{4}{|c|}{ Nov-18 } & \multicolumn{4}{|c|}{ Des-18 } \\
\hline \multirow{2}{*}{ Input } & \multirow{2}{*}{\multicolumn{2}{|c|}{ Zone }} & \multirow{2}{*}{$\begin{array}{c}\text { Water } \\
\text { Distributed }\end{array}$} & \multirow{2}{*}{$\begin{array}{c}\text { Sold water } \\
\text { M3 } \\
\end{array}$} & \multicolumn{2}{|c|}{$\%$ Water Losses } & \multirow{2}{*}{$\begin{array}{c}\text { Water } \\
\text { Distributed }\end{array}$} & \multirow{2}{*}{$\begin{array}{c}\text { Sold water } \\
\text { M3 }\end{array}$} & \multicolumn{2}{|c|}{$\%$ Water Losses } \\
\hline & & & & & M3 & $\%$ & & & M3 & $\%$ \\
\hline \multirow{4}{*}{ IPA PINUS } & Zona M & & 150.292 & 120.170 & 30.122 & $20,04 \%$ & 145.857 & 107.410 & 38.447 & $26,36 \%$ \\
\hline & Zona P & & 105.803 & 78.296 & 27.507 & $26,00 \%$ & 99.801 & 75.197 & 24.604 & $24,65 \%$ \\
\hline & Zamp & & 29.607 & 22.275 & 7.332 & $24,76 \%$ & 29.003 & 21.614 & 7.389 & $25,48 \%$ \\
\hline & MTP & & 177.755 & 100.913 & 76.842 & $43,23 \%$ & 175.113 & 88.831 & 86.282 & $49,27 \%$ \\
\hline \multirow{3}{*}{$\begin{array}{c}\text { IPA } \\
\text { Banjarbakula + } \\
\text { IPA Pinus }\end{array}$} & \multirow{3}{*}{$\begin{array}{c}\text { Boster } \\
\text { Muslimin }\end{array}$} & Trikora & 126.191 & 75.506 & 50.685 & $40,17 \%$ & 103.387 & 69.154 & 34.233 & $33,11 \%$ \\
\hline & & Cempaka & 141.550 & 79.082 & 62.468 & $44,13 \%$ & 119.516 & 70.874 & 48.642 & $40,70 \%$ \\
\hline & & Sei Ulin/BLK & 104.270 & 73.705 & 30.565 & $29,31 \%$ & 90.735 & 68.501 & 22.234 & $24,50 \%$ \\
\hline & TOTAL & & 835.468 & 549.947 & 285.521 & $34,17 \%$ & 763.412 & 501.581 & 261.831 & $34,30 \%$ \\
\hline
\end{tabular}

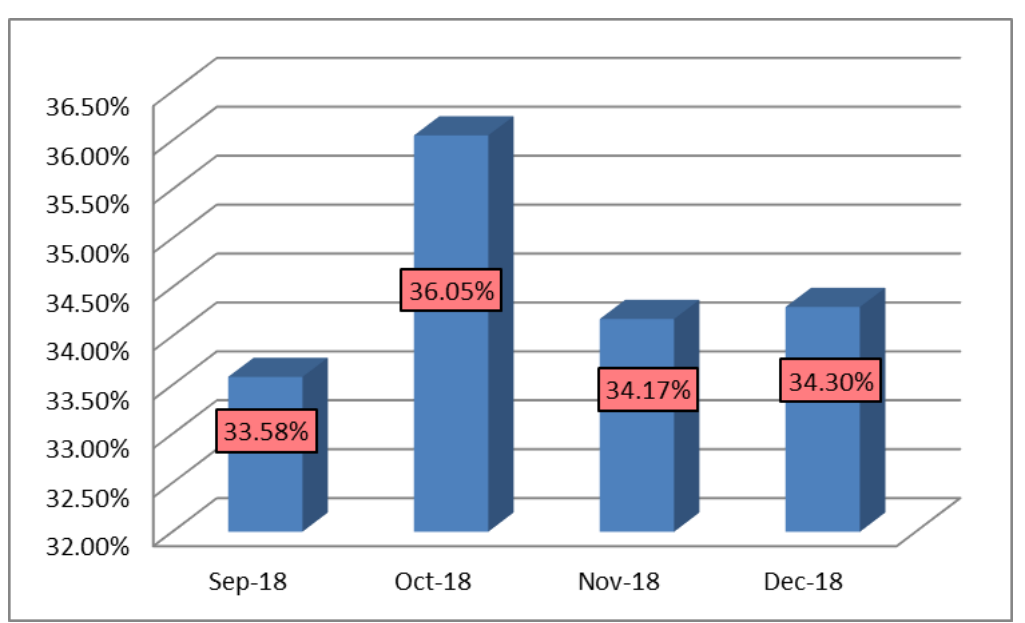

Figure 2. Percentage of Water Losses for September 2018 - December 2018 
The $1^{\text {st }}$ International Conference on Business and Management of Technology (IConBMT)

August 3rd 2019, Institut Teknologi Sepuluh Nopember, Surabaya, Indonesia

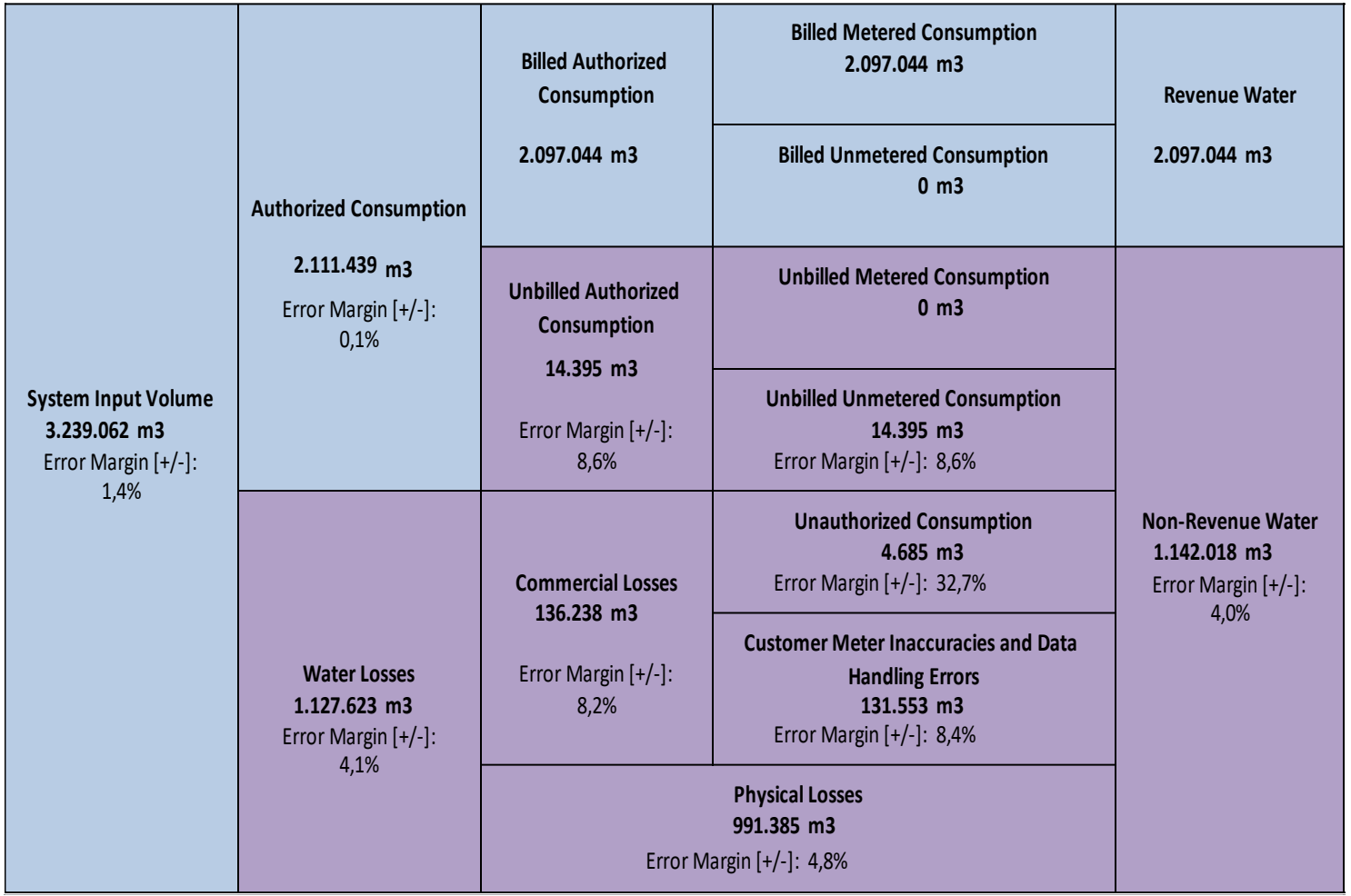

Figure 3. Water Balance of BNA Zone in Intan Banjar Water Supply Company

The water losses consist of real and apparent losses. Real Losses are water losses in a distribution system indicated by real losses and apparent losses The losses of water in the distribution system to customers water supplay company that doesn't out water out of the system. The result from the water balance analysis, percentage of water losses is $34,81 \%$ with the composition of real losses $30,61 \%$ and apparent losses of $4.21 \%$. So it is a matter of concern and action is required for water losses reduction. the percentage of water loss shown in the Figure 4.

Based on the results of observations and interviews with the employees of Intan Banjar water supplay company, if the high real losses was caused by visible and invisible leakages (Background Leakage), pipe fittings connections, and in the connection pipe service to the customer's water meter. This is in accordance with the data in BNA zone has repaired 12.201 points of leakage. The leakage in BNA zone caused by many things including are high pressure, Imperfect pipe connection, Damage to the corrosive pipe, especially in the installed pipe for a long time, Pipe damage due to road repair and drainage project. Cause of real losses shown in the Figure 5.

The Factor of Apparent losses in BNA zone caused by inccuracies meter reading customer and illegal connection. the figure 4 shown that in the greatest apparent losses caused by inccuracies meter reading customer as $4,06 \%$ and This is accordance with based on data from the customer meter accuracy survey that the margin error of customer meter is $5 \%$. The inccuracies costomer meter happened because Intan Banjar water supplay company used class B water meter customer. Class B water meter is lower quality than class c water meter. The accuracy of customer meters is equally important, with the main difference being that there are many more customer meters in operation - and each measures a relatively smaller flow-than production meters. The accuracy of customer mete-ring depends on several factors, including meter type, brand, and replacement policy, maintenance, and water quality. The water supply company should establish guidelines for all of these factors to ensure accuracy of customer consumption data. Customer meters used by Intan Banjar Company be shown in Figure 6.

The water losses distribution system could in a loss of income for the Intan Banjar water suplay. Based on the water balance results using Easycalc Water Balance ver 5.16 it is estimated that water losses on September 2018 to December 2018 For the BNA zone as:

1. Apparent losses is $136.238 \mathrm{~m}^{3}$

2. Real Losses is $991.385 \mathrm{~m}^{3}$.

3. Total water losses are the sum of Apparent losses and real losses, namely $136,238+991,358=$ so that the Calculation is $1.127 .623 \mathrm{~m}^{3}$

With each loss, the deficit of Intan Banjar water supply company could be calculated based on the average water sales rate per $\mathrm{m} 3$, and the average cost of production /distribution of water per $\mathrm{m} 3$ as shown in Table 5. 
The $1^{\text {st }}$ International Conference on Business and Management of Technology (IConBMT)

August 3rd 2019, Institut Teknologi Sepuluh Nopember, Surabaya, Indonesia

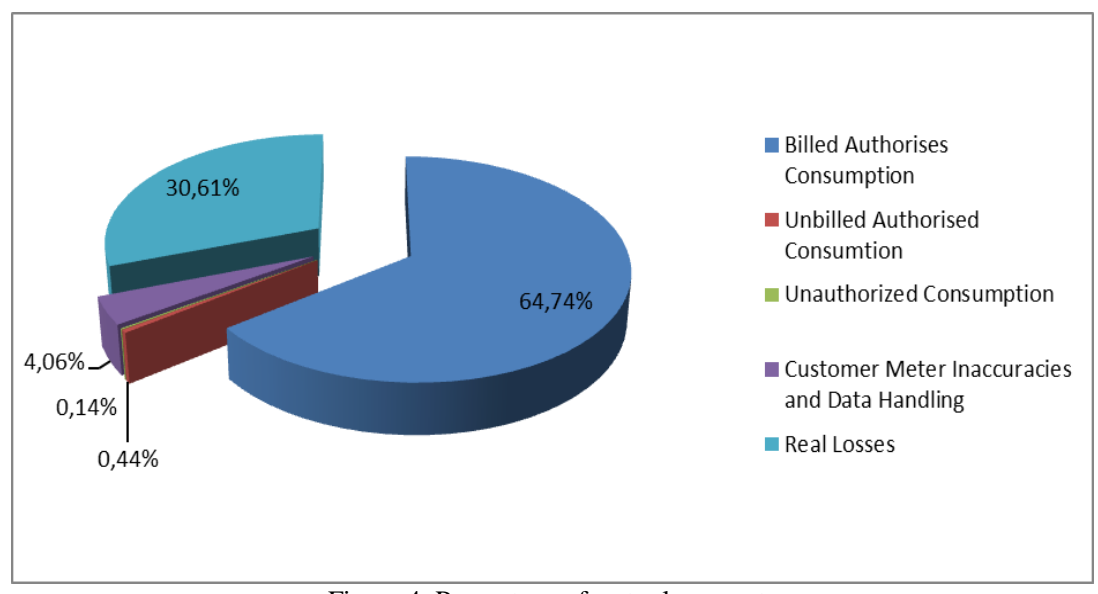

Figure 4. Percentage of water losses rate

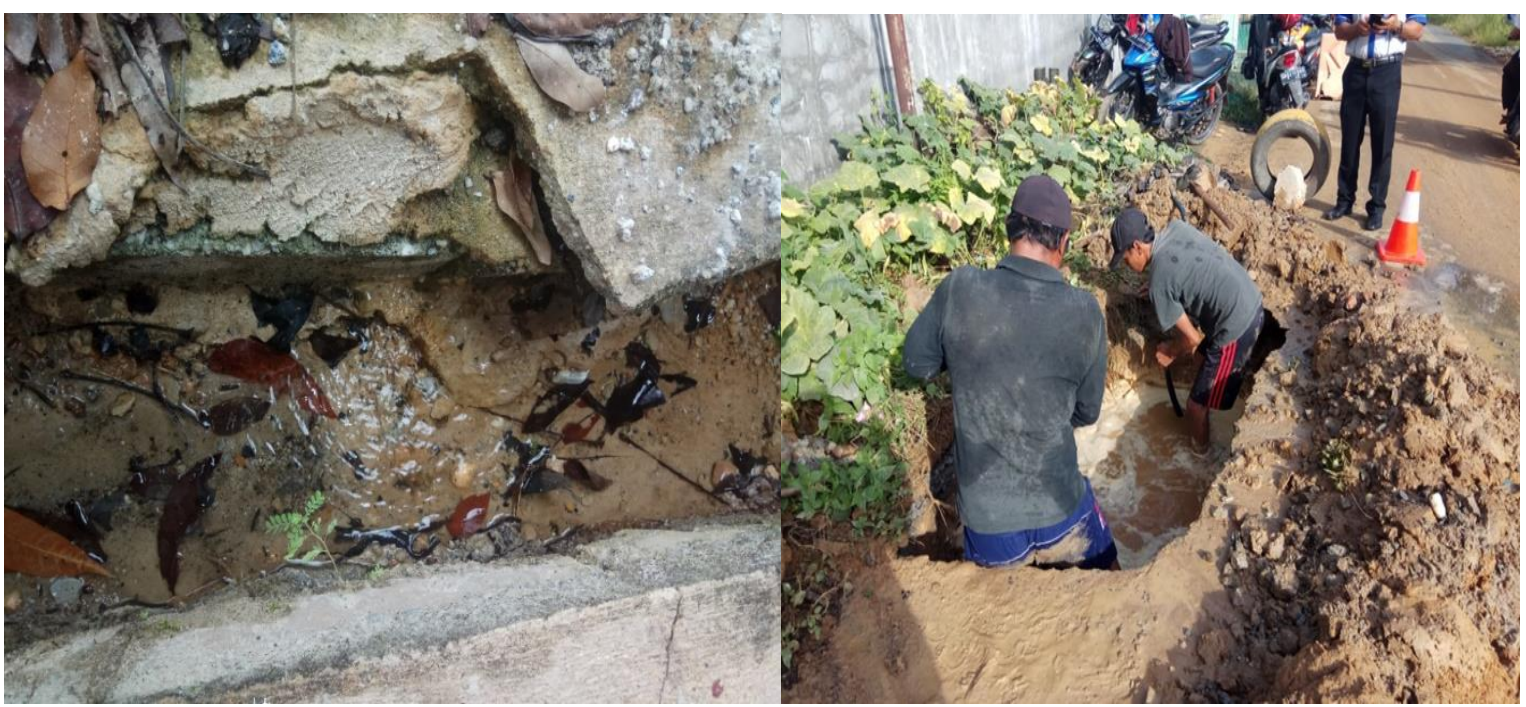

Figure 5. Leaks in house connections and Pipe Distribution Network

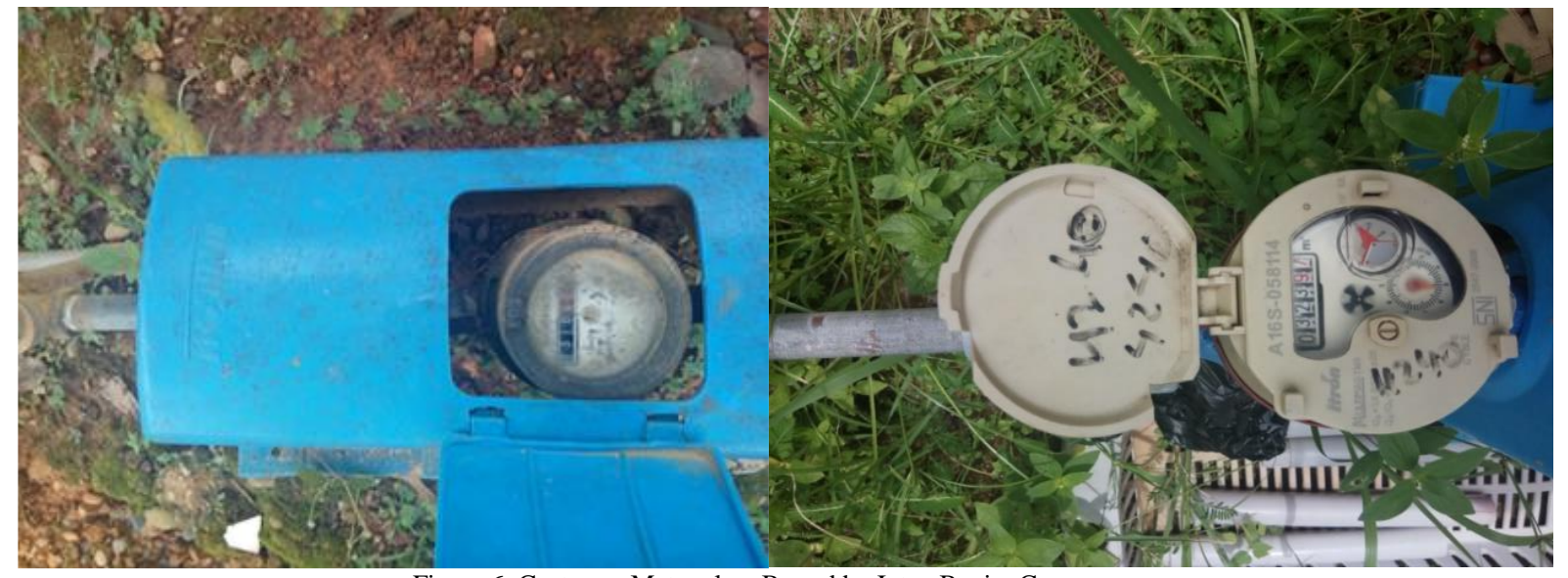

Figure 6. Costomer Meter class B used by Intan Banjar Company

TABLE 5 .

Average Sales Costs AND Production/Distribution Cost

\begin{tabular}{lccccc}
\hline \multicolumn{1}{c}{ Uraian } & Sep-18 & Okt-18 & Nov-18 & Des-18 & Average \\
\hline Average Tariffs (Rp) & 7.129 & 7.128 & 7.179 & 7.164 & 7.150 \\
Production/Distribution Cost (Rp) & 3.608 & 3.692 & 3.653 & 3.653 & 3.651 \\
\hline \hline
\end{tabular}


Deficit received by Intan Banjar water supply company due to water losses could be calculated on September 2018 to December 2018 as follows:

1. Apparent losses must be an air tariff per $\mathrm{m}^{3}$ directly by the company. Deficit of Apparent losses can calculated Rp.7150, - x $136.238 \mathrm{~m}^{3}=$ Rp. 974.101.700,-

2. The real losses water is a leakage of the distribution pipe which will not directly become the income of the water tariff per $\mathrm{m}^{3}$, but will result in a loss of production / distribution costs. So that the losses due to real losses is: Rp. 3651, - x $991.385 \mathrm{~m}^{3}=\mathrm{Rp}$. 3.619.546.635,-

3. The total deficit of Intan Banjar Company due to water losses is the total losses due to Apparent losses and real losses, so the total is Rp. 974.101.700,- + Rp. 3.619.546.635,- = Rp. 4.593.648.335,-

In this instance the action plan needs to control water losses that will maximise benefits which follows the steps below:

- Develop an NRW master plan

The first step is to analyse water distribution system and develop a master plan for water losses reduction. Calculation water balance with a breakdown of the IWA (International Water Association) will help Intan Banjar Company quantify the different water losses elements to prioritise activities and investments to reduce leakage.

- Pressure management

Minimum pressure is defined as $10 \mathrm{~m} \mathrm{H}_{2} \mathrm{O}$ and Maximum pressure is defined as $60 \mathrm{~m} \mathrm{H}_{2} \mathrm{O}$ in the directive.

- Speed and quality of repairs

Municipalities should provide proper repair where pipe bursts are seen

- Maintenance of pipeline systems

Rehabilitation, maintenance, and repairs should be carried out regularly depending on system needs.

- Active leakage control

Municipalities should carry out an active leakage control program using proper monitoring systems

- Pipeline and assets management

Selection and installation of components of a water distribution network should be done properly to prevent physical water losses.

- Forming pressure zones and DMAs (District Meter Area)

These smaller subsystems often referred to as District Meter Area (DMA). Hydraulic modeling should be carried out in existing. DMA must be hydraulically isolated so the company can to calculate the volume of water lost in the DMA.

- The Employment of qualified personnel to control and reduce water losses is necessary as well.

- Tackle apparent losses with the minimum expenditure; reduce unauthorized consumption, meter reading and accounting errors at the first instance which will increase revenue.

- Simultaneously reduce leakage in order to save money in producing/buying less water and Invest savings in further reducing Apparent and Real Losses.

- Tackle apparent losses with the minimum expenditure; reduce unauthorized consumption, meter reading and accounting errors at the first instance which will increase revenue.

- Simultaneously reduce leakage in order to save money in producing/buying less water and Invest savings in further reducing Apparent and Real Losses.

Reducing excessive losses results are more water being available for consumption that can be sold, Delaying the need for capital investments, Lower operating costs, Reducing commercial losses will generate more revenue[5].

\section{CONCLUSION}

This research investigated the problem of water losses in BNA (Basic Need Approach) zone of Intan Banjar water supply company as a case study. The water losses on BNA has experienced a fluctuation. It can be seen that the highest losses occurred in October at $36.05 \%$, but in November the level of water losses decreased to $34.17 \%$. The results water balance revealed that the typical value of water losses in BNA (Basic Need Approach) zone is approximately $34,81 \%$, which is very high according to the government standards. From water balance calculations, composition of real losses as $30,61 \%$ and apparent losses of $4.21 \%$. Also the results show that the main factors that contributed to water losses are the estimation method of water consumption due to meters inaccuracies, and leakages pipes in some parts of the network. On the other hand, the financial impact posed by the water losses was found to be a loss of income for company as Rp. 4.593.648.335,- on September 2018 to Desember 2018 period.

\section{REFERENCES}

[1] Tentang Kebijakan Strategis Nasional Pengembangan Sistem Penyedia Air Minum (KSNP-SPAM), PERMEN PU 20/PRT/M/2006. 2006

[2] H. Alegre, W. Hirnir, J. M. Baptista, R. Parena, and International Water Association., Performance Indicators for Water Supply Services. London: IWA Publishing, 2000.

[3] M. Farley and R. Liemberger, "Developing a non-revenue water reduction strategy: planning and implementing the strategy," Water Sci. Technol. Water Supply, vol. 5, no. 1, pp. 41-50, Mar. 2005.

[4] N. Petroulias, D. Foufeas, and E. Bougoulia, "Estimating water losses and assessing network management intervention scenarios: The case Study of the water utility of the City of Drama in Greece," Procedia Eng., vol. 162, pp. 559-567, Jan. 2016.

[5] I. Simbeye, Managing Non-Revenue Water. Non-Revenue Water (NRW) Sourcebook for Trainers WAVE Programme. Leipzig, Germany: InWEnt - Internationale Weiterbildung and Entwicklung, 2010. 